\title{
Experimental evaluation of coupler behavior for mechanical rebar splices in reinforced concrete structures
}

\section{Avaliação experimental de luvas para emendas mecânicas de barras de aço em estruturas de concreto armado}
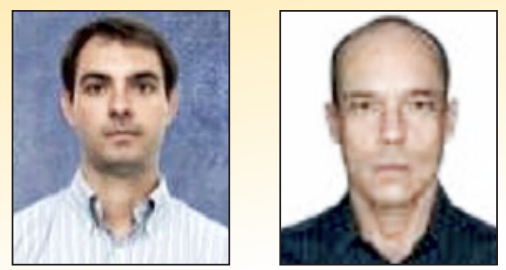

V. G. CHIARI a, b

chiari.victor@gmail.com

A. L. MORENO JUNIOR a almoreno@fec.unicamp.br

\begin{abstract}
The use of mechanical splices to connect steel bars is an important solution in many infrastructure projects worldwide. In Brazil, this system is rarely used. The Brazilian standards regarding this subject are old and out of date; particularly with regard to the performance evaluation test methods for these splices in the laboratory. This paper presents and discusses the test procedure proposed in the international standard ISO 15835 [1] in light of the current procedure defined by Brazilian Standard ABNT NBR 8548 [2], applied to types of mechanical splices commonly used in Brazil: taper threaded and bolted couplers. Performance parameters for these mechanical splicing systems related to structural integrity in reinforced concrete structures are evaluated on the basis of the results obtained in these tests. In the end, it is intended that this paper provide support for discussion of design procedures and laboratory performance evaluation of couplers for mechanical splices of steel bars in reinforced concrete structures in future reviews of Brazilian standard ABNT NBR 8548 [2].
\end{abstract}

Keywords: coupler, reinforced concrete, mechanical splice, rebar.

\section{Resumo}

A utilização de emendas mecânicas para unir barras de aço é uma importante solução em muitas obras de infraestrutura no mundo todo. No Brasil este sistema ainda é pouco difundido. Além disso, a normalização Brasileira sobre o assunto é antiga, está defasada e carece de atualização; principalmente no que diz respeito aos métodos de ensaio para avaliação de desempenho destas emendas em laboratório. Este trabalho apresenta e discute o procedimento de ensaio proposto na norma internacional ISO 15835 [1] à luz do procedimento atual da norma Brasileira ABNT NBR 8548 [2], aplicado aos tipos de emendas mecânicas usualmente empregadas no Brasil: luvas rosqueadas tipo cônica e parafusadas. Parâmetros de desempenho destes sistemas mecânicos de emenda de barras de aço, relacionados à integridade estrutural em construções de concreto armado são avaliados com base nos resultados obtidos nestes ensaios. Pretende-se, assim, que este trabalho ofereça subsídios para discussão de procedimentos de avaliação de desempenho de luvas para emendas mecânicas de barras de aço em estruturas de concreto armado, nas futuras revisões da norma Brasileira ABNT NBR 8548 [2].

Palavras-chave: luva, concreto armado, emenda mecânica, barra de aço. 


\section{Introduction}

The steel bar splicing region is always treated with special attention in guidelines, codes of practice, and norms that specify parameters for the dimensioning of structural elements in reinforced concrete. As an example, it must be ensured that these splices are implemented in a way that does not interfere with the originally planned behavior of the structural element in the region where they are located. Tensions in the structural element arising from inefficient splices should be avoided, because of the risk of the consequent undesired redistribution of force throughout the element and even the structure as a whole. It must therefore be assumed that the performance of a structural element, or even of a reinforced concrete structure, is directly related to the successful use of best practices in the event of splicing of its steel bars.

Steel bars are generally spliced by lapping, by welding, or through mechanical systems using steel couplers. The lap splice is a solution already consolidated in the world market, being the most used system in reinforced concrete structures, mainly because it is the least expensive method. However, there are situations where this type of splice cannot be used, such as in the case of execution errors in the length of pillar starters, or "waits", and especially in cases of structural restoration or reinforcement interventions, or even when it is desired to splice steel bars with diameters greater than the limit established for the lap splicing system. In such cases, designers may employ welded steel bars seams or steel couplers. In weld splicing, the steel bars are spliced by top-welding, by heating or electricity; or through copper-joints, with pressure-type autogenous solder being preferable. This type of splice has fallen into disuse in recent years, mainly due to the need for specialized labor and the time required for execution and strict quality control. Although it is, in many situations, the most expensive of the three systems presented, the recognized effectiveness of the coupler splicing system must be emphasized (Figure 1). According to Singhr et al. [3], the main advantages of using couplers for mechanical splicing are:

- Reduced steel frame congestion problems;

- Control of concrete crack propagation;

- Improvement in the structural continuity between bars, generating greater security;

- Reduction of labor and consequently the overall cost of the structure;

- Possibility of joining bars of any length and diameter.

Mechanical splices have been used in Brazil since the 1970s and have been utilized in very significant projects in the Brazilian and international scenario (the Angra I and II nuclear power plants and the Itaipu hydroelectric dam). However, the mechanical splicing of steel bars is still underused as a method when compared to the conventional lap splice.

Currently, it is possible to find a great variety of couplers in the Brazilian market. Among the most commonly used models are the taper-threaded, shear bolted, cold-swaged, straight-threaded, and steel-filled, whose technical characteristics are presented in Table 1. There are few national publications currently evaluating couplers for the splicing of steel bars, which are mainly tested in isolation, i.e. without being inserted into a reinforced concrete structure. Even internationally, the subject is quite new and it is only in the

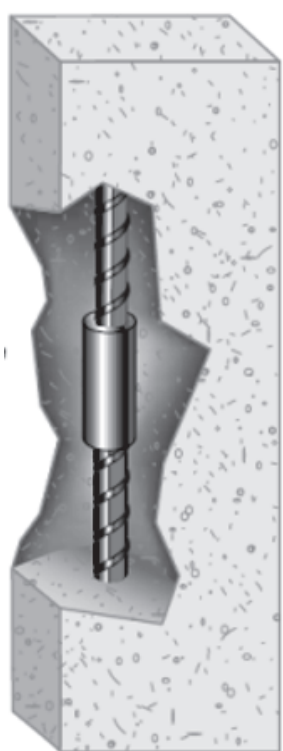

\section{Figure 1}

Illustration of a mechanical coupler splice applied at the point of union of a steel bar

last 20 years that mechanical splices have been studied more frequently, due to the worldwide demand for this type of solution in major infrastructure projects.

Nouredine [4], Hillis \& Saiidi [5], Rowell et al. [6], Alam et al. [7], and Huaco \& Jirsa [8] presented the first international results on the performance of couplers as mechanical splice for steel bars.

In a more complete study, Lloyd [9] evaluated the behavior of steel bars spliced with shear bolted couplers, 20 and $25 \mathrm{~mm}$ in diameter, under static and dynamic loads, according to the standard established by ASTM 1034 [10]. The results obtained proved the efficiency of this type of splice.

The effectiveness of the instrumentation used to evaluate the performance of these mechanical splices was approached in the research carried out by Alam et al. [7], Connah [11], Taskin [12], Klimenov et al. [13], Ling et al. [14], and Seo et al. [15]. In this case, the proposed instrumentation had the objective of collecting deformation and/or displacement data, both on the part of the steel bar and splice coupler, in order to evaluate any possible relative slip between these two elements.

More recently, Haber et al. [16] evaluated the performance of two types of steel coupler: taper-threaded and grout-filled (filled with a cementitious mortar and applied only to precast structures) with a diameter of $20 \mathrm{~mm}$, according to the method specified in CALTRANS 670 [17], very similar to the method proposed by ISO 15835 [1]. The results of these tests proved the efficiency of the proposed method, mainly with respect to the instrumentation used, where electrical extensometers were installed on the steel bars and on the couplers and displacement transducers were positioned on the bars to determine the relative displacement between bar and coupler. In the study by Nguyen \& Mutusuyoshi [18], the performance of grout-filled couplers in the mechanical splicing of steel bars was evaluated. The test method was basically the same as that employed by Haber et al. [16] with subtle differences but proven effective 
in its instrumentation. In this study, the displacement transducers were not fixed to the bars, but to a hexagonal steel base specially made by the authors. Such instrumentation proved to be efficient in evaluating the relative slip between steel bar and coupler.

Finally, it is important to highlight the importance of this type of splice in the connection of prefabricated concrete elements. This type of linking has been studied in Brazil over the past 25 years, with some recent highlighted works being Ferreira [19], Ballarin [20], Ferreira [21], Jeremias Junior [22], Souza [23], and Catoia [24]. These studies are taken as references in the Brazilian technical literature and supported the recently published revision of ABNT NBR 9062 [25]. With regard to international references, this type of study was conducted by Ordoñez et al. [26], Cheok and Lew [27], Haber et al. [28] and Yu et al. [29].

When the various studies on the behavior of steel coupler mechanical splices in reinforced concrete structures are put into context, a lack of national publications on the subject is noted, both with regard to the individual performance evaluation of these mechanical splices and the evaluation of these splices together with reinforced concrete structural elements.

Therefore, the current article has the aim of presenting to the national technical environment a necessary performance evaluation of some types of mechanical splices utilized by the national construction industry, and also to present support for discussion of procedures (design and laboratory performance evaluation) in the future revision of ABNT NBR 8548 [2], when these procedures are compared to those established by international standard ISO 15835 [1].

\section{Mechanical splice performance parameters}

It is assumed in the design that the potential presence of a mechanical splice between two reinforcing bars will not result in a reduction of the structural strength, or of the stiffness or ductility of the spliced bar. The current set of standards for concrete structure projects is based on this principle, specifying details of the configuration of these splices that are more linked to how the steel and concrete work together than to guaranteeing the adequate structural behavior of the mechanical splice in question. Hence the importance of guaranteeing the performance of these splices, linked to the evaluation of specific parameters of interest through standardized laboratory tests.

The performance evaluation of the mechanical steel splicing system in Brazil should follow the standard established by ABNT NBR 8548 [2], which, it is important to mention, requires revision to insert parameters and performance-specific test methodologies for the various types of couplers currently in use in the national construction industry.

Internationally, the ISO 15835 [1] standard is much more complete than its national equivalent, however it is still lacking in improvements in the model instrumentation standard for obtaining desired performance parameters. In this sense, it is important to note the adaptation to this instrumentation standard proposed by Haber et al. [16] and Nguyen \& Mutusuyoshi [18].

Two performance parameters are essential in evaluating

Table 1

Mechanical splice couplers available on the brazilian market

\begin{tabular}{|c|c|c|}
\hline Mechanical splice coupler & Advantages & Disadvantages \\
\hline Taper-threaded & $\begin{array}{l}\text { - Similar cost to lap splice } \\
\text { - Easy to execute } \\
\text { - Uniform distribution of stress along } \\
\text { the entire connected section } \\
\text { - Excellent productivity } \\
\text { - Self-alignment } \\
\text { - Quality control through use of torque wrench } \\
\text { - Special equipment for carving threads }\end{array}$ & $\begin{array}{l}\text { - Necessary to prepare the ends of the } \\
\text { steel bars } \\
\text { - Not possible to carve threads on bars } \\
\text { already installed } \\
\text { - Positioning sleeve necessary to use on } \\
\text { deformed bars }\end{array}$ \\
\hline Shear bolted & $\begin{array}{l}\text { - Steel bar ends do not require preparation } \\
\text { - Can be used for emergencies when bar } \\
\text { is already installed } \\
\text { - Quick and easy installation } \\
\text { - Excellent productivity } \\
\text { - Visual quality control (bolt will shear } \\
\text { when it reaches the specified torque) }\end{array}$ & $\begin{array}{l}\text { - High cost } \\
\text { - Difficult to splice deformed bars }\end{array}$ \\
\hline Cold-swaged & $\begin{array}{l}\text { - Does not require preparation of the steel } \\
\text { bar ends } \\
\text { - Can be used on already-installed bars } \\
\text { - Similar cost to lap splice }\end{array}$ & $\begin{array}{l}\text { - Swaging press very heavy and difficult to } \\
\text { install in tall buildings } \\
\text { - Difficult inspection and quality control } \\
\text { - Low productivity }\end{array}$ \\
\hline Straight-threaded & $\begin{array}{l}\text { - Similar cost to lap splice } \\
\text { - Good productivity } \\
\text { - Special equipment for carving threads }\end{array}$ & $\begin{array}{l}\text { - Necessary to prepare the ends of the } \\
\text { steel bars } \\
\text { - Not possible to carve threads on bars } \\
\text { already installed } \\
\text { - Visual quality control } \\
\text { - Difficult to properly align bars during } \\
\text { installation }\end{array}$ \\
\hline Steel-filled & $\begin{array}{l}\text { - Does not require preparation of the steel } \\
\text { bar ends } \\
\text { - Low cost }\end{array}$ & $\begin{array}{l}\text { - Difficult to install } \\
\text { - Low productivity } \\
\text { - Requires specialized labor } \\
\text { - Onerous quality control }\end{array}$ \\
\hline
\end{tabular}


Table 2

International standard $\mathrm{f}_{\mathrm{y}}$ and $\mathrm{f}_{\mathrm{st}}$ values for steel grade identical to CA 50

\begin{tabular}{ccccc}
\hline Country & Standard & Steel grade & Yield stress $\mathrm{f}_{\mathrm{y}}(\mathrm{MPa})$ & Maximum tensile stress $\mathrm{f}_{\mathrm{st}}$ \\
\hline Germany & DIN 1045 [31] & $500 \mathrm{M}$ & 500 & $550\left(1.10 \mathrm{f}_{\mathrm{y}}\right)$ \\
Austria & ONORM B4700 [32] & 550 & 550 & $620\left(1.13 \mathrm{f}_{\mathrm{y}}\right)$ \\
France & NF-A-32-020 [33] & 500 & 500 & $550\left(1.10 \mathrm{f}_{\mathrm{y}}\right)$ \\
Netherlands & BRL-0504 [34] & 500 & 500 & $550\left(1.10 \mathrm{f}_{\mathrm{y}}\right)$ \\
\hline \multirow{2}{*}{ United Kingdom } & BS 8110 Appendix & B500A & $500\left(1.05 \mathrm{f}_{\mathrm{y}}\right)$ & $540\left(1.08 \mathrm{f}_{\mathrm{y}}^{\mathrm{y}}\right)$ \\
& TA1-B [35] & B500B & & $575\left(1.10 \mathrm{f}_{\mathrm{y}}^{\mathrm{y}}\right)$ \\
\hline
\end{tabular}

mechanical steel bar splices: tensile strength (yield stress, $f_{y}$, and maximum tensile stress, $\left.f_{s t}\right)$ and the relative slip between bar and coupler. Similar to Brazilian standard ABNT NBR 8548 [2], ISO 15835 [1] refers to the necessary similar behavior in terms of yield stress for both spliced and seamless bars.

In Brazil, the minimum required value for the yield stress of a bar connected by mechanical splicing is that prescribed by ABNT NBR 8548 [2], which establishes that the results obtained in the tensile stress tests on steel bars, with or without the couplers, must meet the minimum requirements defined by ABNT NBR 7480 [30], that is, for CA 50 type bars, $f_{y}$ must be $500 \mathrm{MPa}$, while $\mathrm{f}_{\mathrm{st}}$ should be 540 $\mathrm{MPa}\left(1.08 \mathrm{f}_{\mathrm{y}}\right)$. Table 2 presents the main international standards for these same parameters and their respective minimum values for steels of similar classes [31] [32] [33] [34] [35].

Although not specified in the scope of ABNT NBR 8548 [2] and rarely taken into consideration for construction projects in Brazil (other than nuclear power plants), the relative slip between bar and coupler is equally important to the structural evaluation, since it serves to measure the displacement tendency of the steel bar in relation to the coupler under extreme load conditions and, consequently, the reliability of the structural continuity.

International standard ISO 15835 [1], used as the main reference for this study, recommends a maximum slip limit of $0.1 \mathrm{~mm}$. This limit is also set out in the internal specifications of Eletrobrás Eletronuclear, known as DS-G-6647-029202 [36], which was created and has been used in addition to ABNT NBR 11561 [37], which became obsolete in 2002. The slip limit value is also related to the control of concrete cracking in the region around the splice.

\section{Experimental program}

The premise of the experimental program of this study was to evaluate the procedures proposed in ISO 15835 [1] in the light of the national procedures of ABNT NBR 8548 [2], with instrumentation adapted according to Haber et al. [16] and Nguyen \& Mutusuyoshi [18], for the mechanical splicing of steel bars with taper-threaded and shear bolted couplers.

The characterization tests of the unspliced steel bars, here called "control bars", were carried out in the Laboratory of Construction Materials and Concrete at the Military Engineering Institute (IME) in Rio de Janeiro.

The second part of the experimental program, and the main focus of this study, was composed of tensile stress and slip tests on these same mechanically spliced bars, and was carried out in the Structures and Materials Laboratory at the State University of Campinas (UNICAMP).

In light of the objective of this study to comprehensively analyze and compare the behavior of splice couplers with different tests and instrumentation (test method) described in the national and international literature, three different test methods were used to evaluate the spliced bars. Table 3 details the three different methods used (ABNT NBR 8548 [2], ISO 15835 [1] and DS-G$6647-029202$ [36]), the number of loading cycles to obtain slip (1 or 3 cycles) and the arrangement of the transducers to obtain the relative slip between bar and splice (suggested by Haber et al. [16] and Nguyen \& Mutusuyoshi [18])

The two types of mechanical splices to be evaluated were chosen because of their recent use in Brazil and because they are currently the types most specified in structural designs as a solution for the mechanical splicing of steel reinforcement bars in concrete structures worldwide. The diameters of the spliced bars, $20 \mathrm{~mm}$ and $25 \mathrm{~mm}$, were also chosen because they are commonly used and of a size where the size of lap splices becomes so large the mechanical splicing with couplers becomes a more promising

\section{Table 3}

Test procedures applied to mechanically spliced bars

\begin{tabular}{cccc} 
& Method 1 & Method 2 & Method 3 \\
\cline { 2 - 4 } Stress resistance & ABNT NBR 8548 [2] & ISO 15835 [1] & ISO 15835 [1] \\
\hline Slip & $\begin{array}{c}\text { Adaptation of DS-G-6647- } \\
\text { O29202 [36] with the } \\
\text { application of a single load } \\
\text { cycle }\end{array}$ & $\begin{array}{c}\text { ISO 15835 [1] with the } \\
\text { application of three load } \\
\text { cycles }\end{array}$ & $\begin{array}{c}\text { ISO 15835 [1] with the application } \\
\text { of three load cycles }\end{array}$ \\
\hline Instrumentation & $\begin{array}{c}\text { Adaptation of Haber et al. } \\
{[16], \text { electrical extensometers }} \\
\text { and individual transducers }\end{array}$ & $\begin{array}{c}\text { Adaptation of Haber et al. } \\
\text { [16], electrical extensometers } \\
\text { and individual transducers }\end{array}$ & $\begin{array}{c}\text { Adaptation of Nguyen \& } \\
\text { Mutusuyoshi [18], electrical } \\
\text { extensomgeters and transducers } \\
\text { arranged in groups of three }\end{array}$ \\
\hline
\end{tabular}




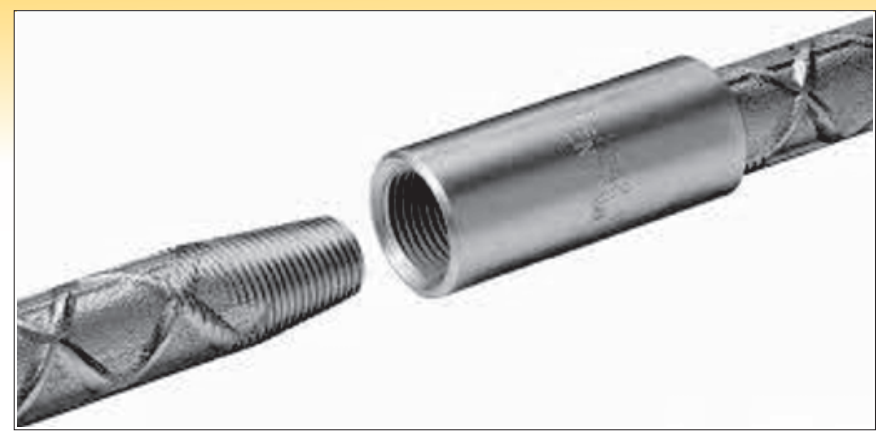

Figure 2

Taper-threaded coupler [38]

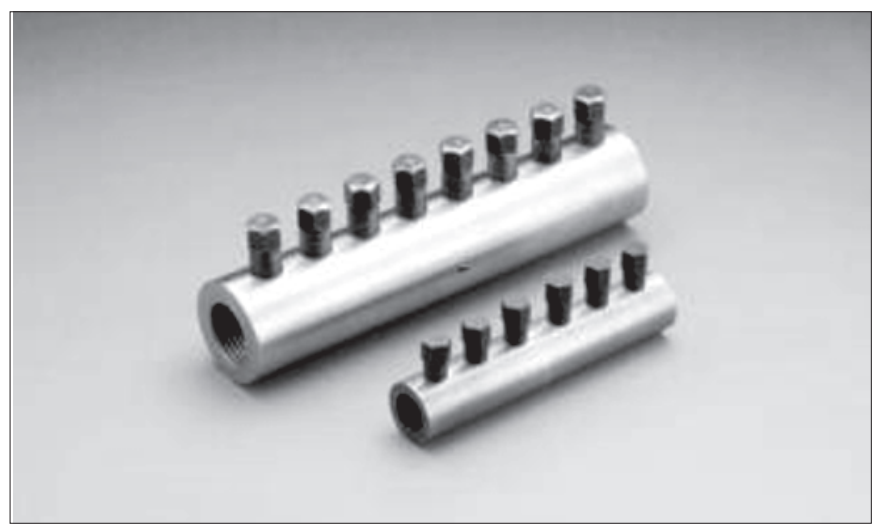

Figure 3

Shear bolted coupler [39]

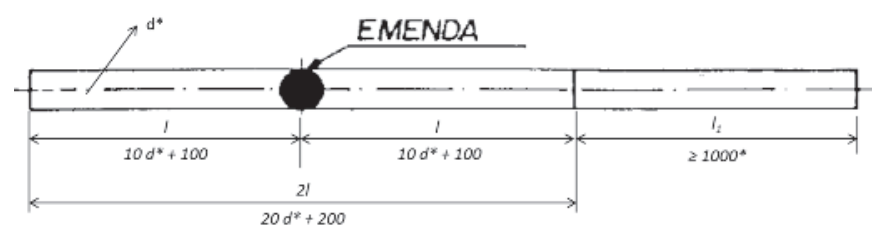

"Diameter "d" of the steel bar and other dimensions should be measured in mm

\section{Figure 4}

Sample for mechanical splice qualification test, modified from ABNT NBR 8548 [2] option, according to the consensus in the national technical environment.

\subsection{Materials}

The materials used in this study were as follows:

- CA 50 type steel bars, with diameters of 20 and $25 \mathrm{~mm}$;

- Shear bolted couplers ${ }^{1}$ (Figure 2 [38]): composed of torquimetric bolts that allow the full force of the steel bar to be used and improve the structural integrity in both traction and compression;

- Taper-threaded coupler ${ }^{2}$ (Figure 3 [39]): manufactured with tapered thread at both ends.

\subsection{Sample dimensions}

In order to verify the physical and mechanical properties of the steel bars used in this study, the requirements described in the national standard ABNT NBR 6152 [40], ABNT NBR 7480 [30], and ISO 15630 [41] were followed, including those dealing with sample size. The national ABNT standard NBR 8548 [2] specifies that steel bars should be separated into three distinct segments $\left(I_{1}\right.$ and $\left.2 I\right)$ as shown in Figure 4, and the mechanical performance of isolated bar of length $I_{1}$, whose minimum length should be $1000 \mathrm{~mm}$ should be evaluated, along with that of the spliced bar of length 21 . It should be noted that the lengths of the indicated bar segments depend solely on the diameter of the steel bar $(d)$ to be evaluated, and thus are independent of the type of splice employed.

In a similar manner, the size of the spliced bar samples, as recommended by ISO 15835 [1] (Figure 5) should be calculated as a function of the diameter of the bar, $d$, to be spliced. However, the length of the coupler $\left(L_{1}\right)$ used should be considered when calculating this segment.

\subsection{Characterization tests of seamless steel bars (control bars)}

Whether for the control bars (bars without mechanical splices) or for the bars with splice couplers, representative sampling for each

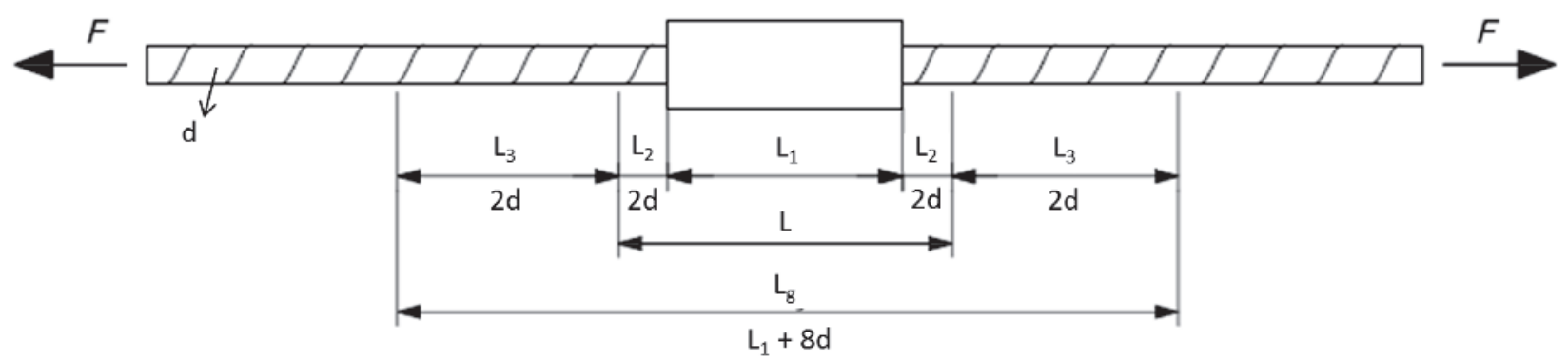

\section{Figure 5}

Dimensions of sample to test mechanical splice performance, modified from ISO 15835 [1]

1 This system is being used more and more frequently in Brazil, especially in emergency situations, where conventional couplers cannot be used, because there is no need for any type of preparation of the steel bar ends (threads). Its installation is performed with an impact wrench and the bolt head shear occurs when the specified torque is reached, allowing for visual quality control.

2 This connection system is the one most used around the world due to its ease of alignment with the steel bar during installation. This splice is carried out using specially developed equipment. For proper quality control, the use of a torque wrench is indispensable. 


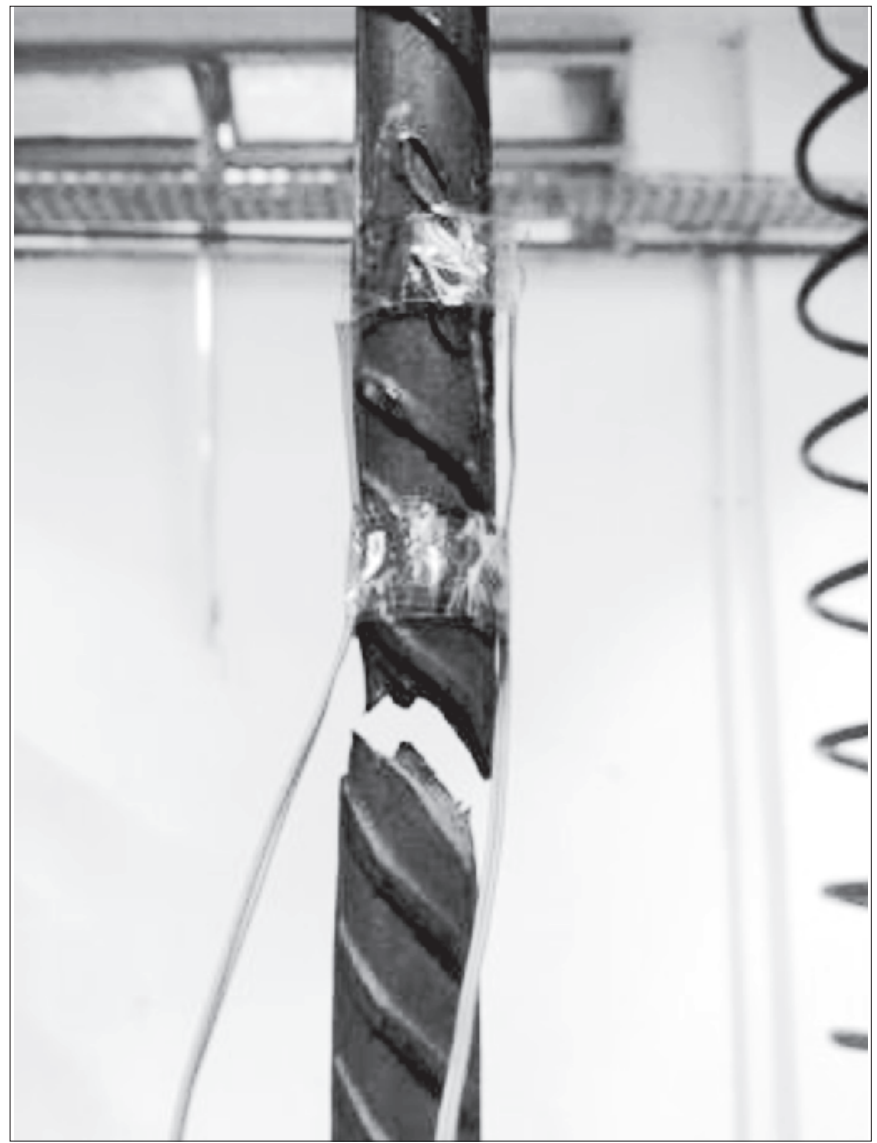

\section{Figure 6}

Detail of control bar rupture after tensile stress test type of coupler, diameter, and test method must be composed of three samples, according to Brazilian standard ABNT NBR 7480 [30] and international standard ISO 15630 [41].

Following the methodology proposed by ABNT NBR 6152 [40], six bars of CA 50 type steel, three being $20 \mathrm{~mm}$ in diameter and another three being $25 \mathrm{~mm}$, were tested in an isolated manner in order to characterize them with regard to tension and compression, in addition to verifying if they met the minimum values for yield stress $\left(f_{y}\right)$ and maximum tensile stress $\left(f_{\text {st }}\right)$ imposed by ABNT NBR 7480 [30].

To perform these tests, a universal test machine with a capacity of $1000 \mathrm{kN}$ and automatic load control was used: Automatic Progressive Loading.

The tensile stress tests were based on Brazilian standard ABNT NBR 6152 [40]. The instrumentation of the control bars was set up by installing two electric strain gauges exactly at the center of the bars, on opposite sides, in order to measure the deformation of the steel bar at this central point throughout the test. Both extensometers were connected to a Vishay model P3 portable data acquisition unit. Figure 6 shows the steel bar after having ruptured, with detail of the installed electrical extensometers.

\subsection{Principal tests: behavior of mechanically spliced bars to tension}

Three tests were performed for each diameter, coupler type, and instrumentation method, making a total of 36 tests, whose purpose was to measure the tensile strength and slip of the samples with mechanical splices. Although Brazilian standard ABNT NBR 8548 [2] does not specify the slip parameter in its scope, it was measured in all trials.

The tests of the bars spliced with couplers were carried out in a universal testing machine with capacity of $1000 \mathrm{kN}$ and automatic loading control. Figure 7 illustrates the dimensions of the sample
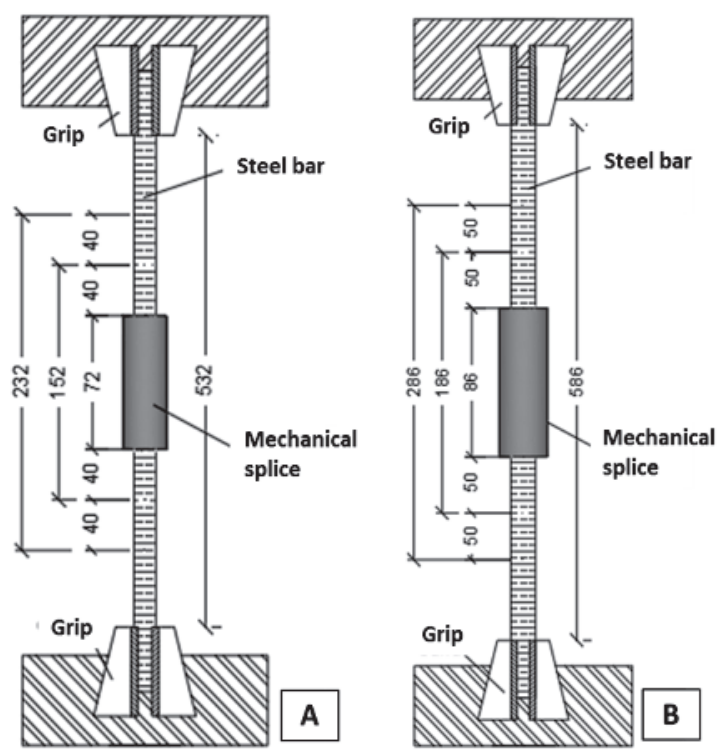

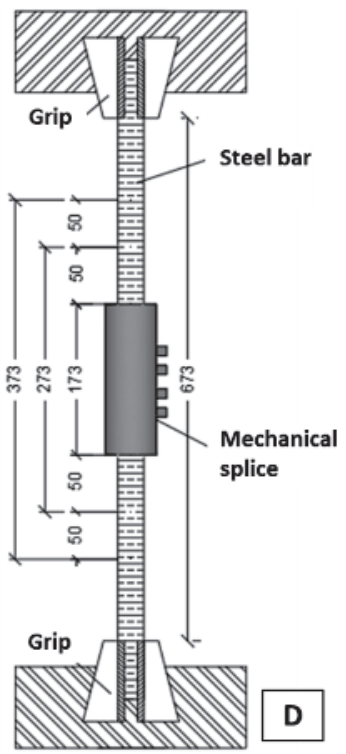

\section{Figure 7}

Sample sizes according to ISO 15835 [1]. A - taper-threaded sleeve 20 mm; B - taper-threaded sleeve 25 mm; C - bolted coupler $20 \mathrm{~mm}$ and D - bolted coupler $25 \mathrm{~mm}$ 

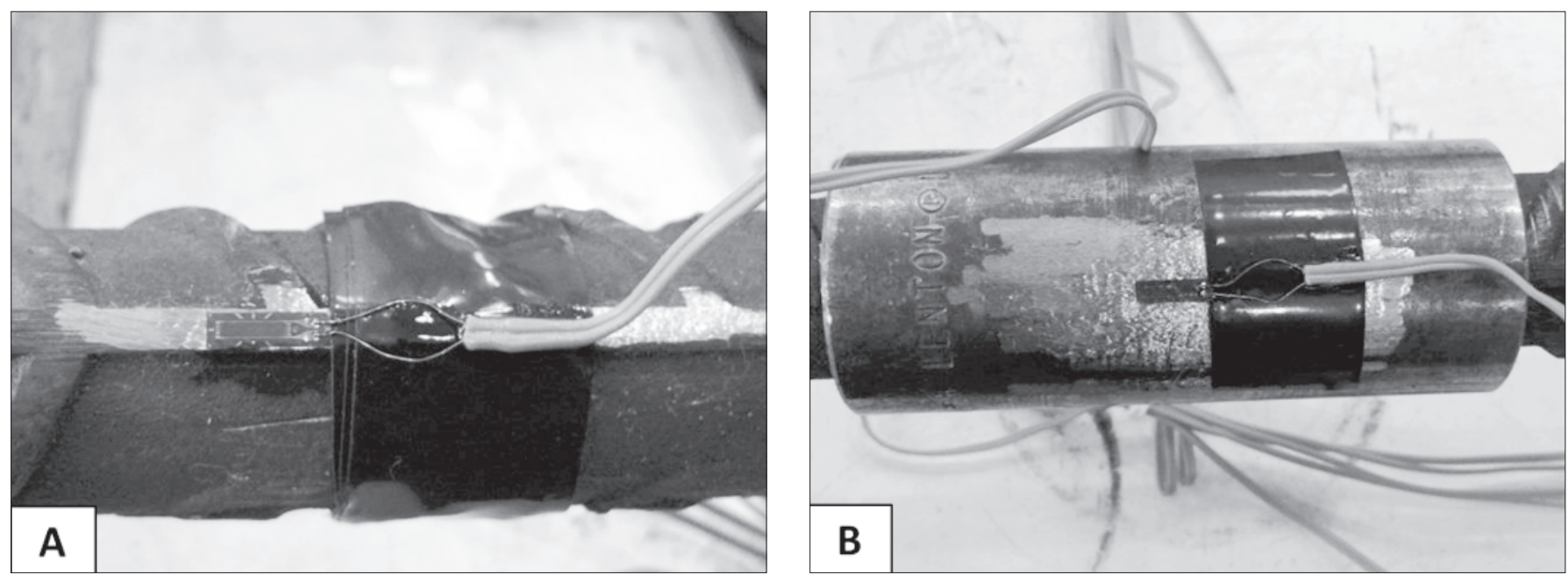

Figure 8

Detail of electrical extensometers: A - steel bar and B - coupler

spliced bars, according to ISO 15835 [1], which considers the length of the type of coupler used in the splicing.

As suggested by Haber et al. [16] and Nguyen \& Mutusuyoshi [18], four electrical extensometers were installed on each spliced bar, two of them on the steel bar (Figure $8 \mathrm{~A}$ ) at a distance of $2 d$ from the outer edge of the coupler and two in the center of the mechanical splice itself (Figure 8B) in order to measure the deformation of the steel bar and compare it to the deformation of the coupler itself during the test.

As additional measuring instruments to measure the relative slip between bar and coupler, displacement transducers were

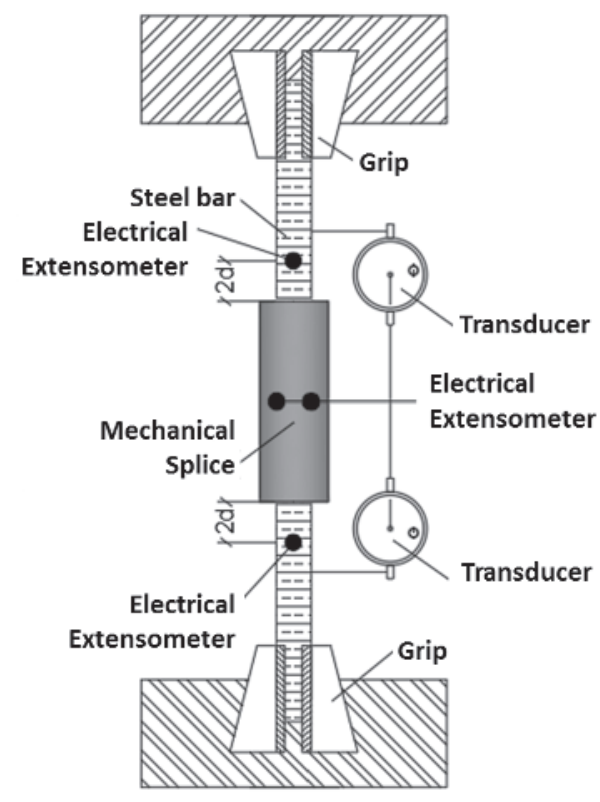

\section{Figure 9}

Instrumentation scheme with individual transducers used in test methods 1 and 2 also positioned in each test. Figure 9 and Figure 10 illustrate the instrumentation applied to Methods 1 and 2, where the transducers were arranged individually and connected directly to the steel bar and the mechanical splice. Figure 11 and Figure 12 show the transducers mounted in groups of three, coupled to an apparatus specially developed for this study (Method 3). Figure 13 shows details of this apparatus.

In order to measure the relative slip parameter between bar and splice, the recommendations of ISO 15835 [1], adapted by DS-G6647-029202 [36], were adopted in this study, which establishes the maximum slip limit to be $0.1 \mathrm{~mm}$. This parameter was measured at

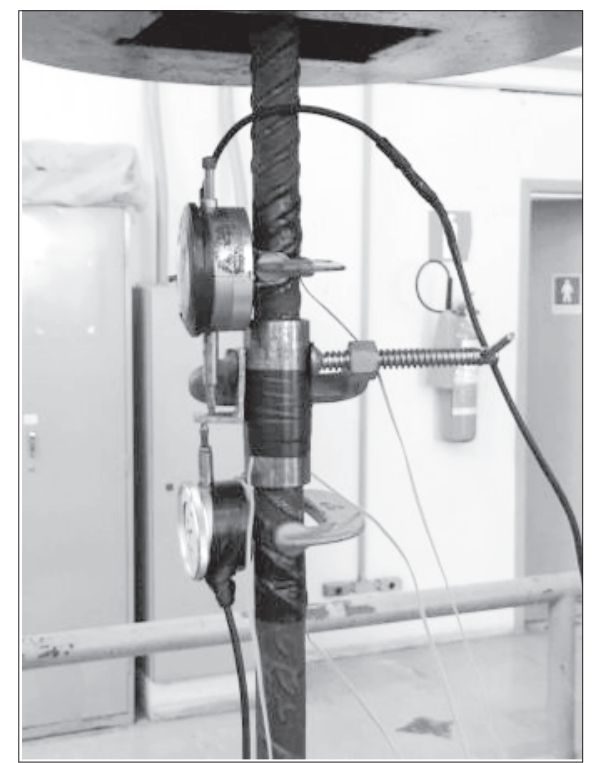

\section{Figure 10}

Individual displacement transducers used in the measurement of the slip parameter in test methods 1 and 2 
the end of a load cycle (Method 1) or at the end of three load cycles (Methods 2 and 3) on the spliced bar (Figure 14). During each cycle the sample was loaded to the specified service rated load for the spliced steel bar (300 MPa in the case of the bars in this study) and then unloaded. After determining the relative slip parameter the samples were loaded until breaking in order to determine the tensile strength parameters and consequent measurement.

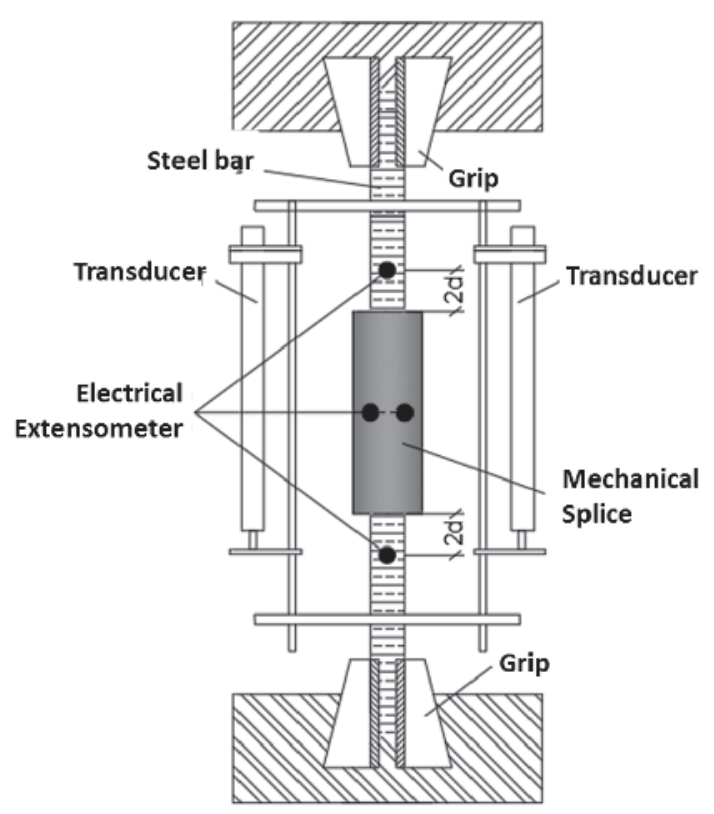

\section{Figure 11}

Instrumentation scheme of transducers installed in groups of three used in test method 3

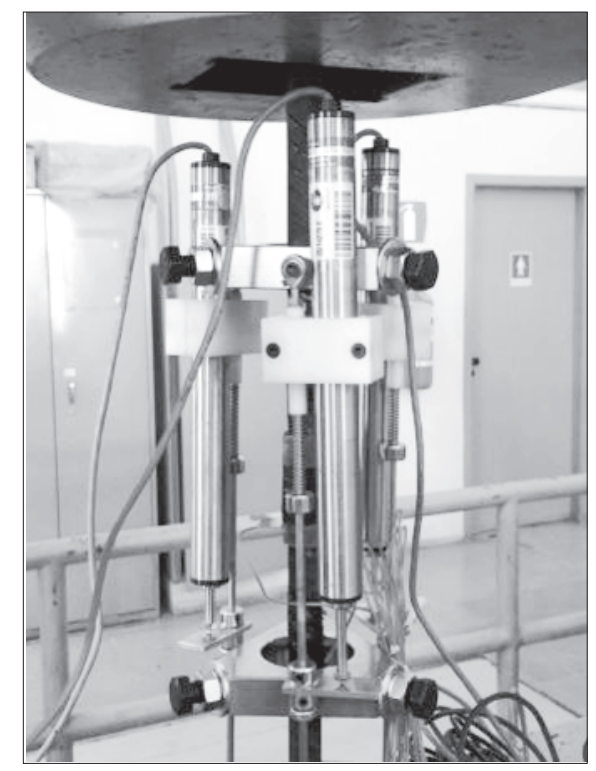

\section{Figure 12}

Transducers in groups of three installed on the fixed triangular steel bases used in test method 3

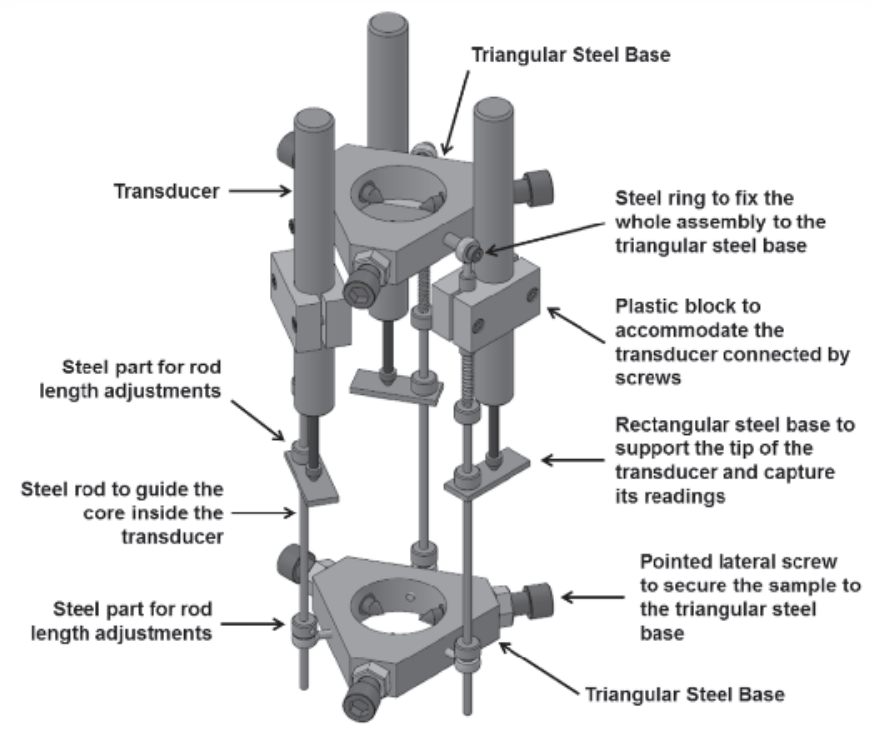

Figure 13

Three-dimensional detail showing the functions of the apparatus used in test method 3
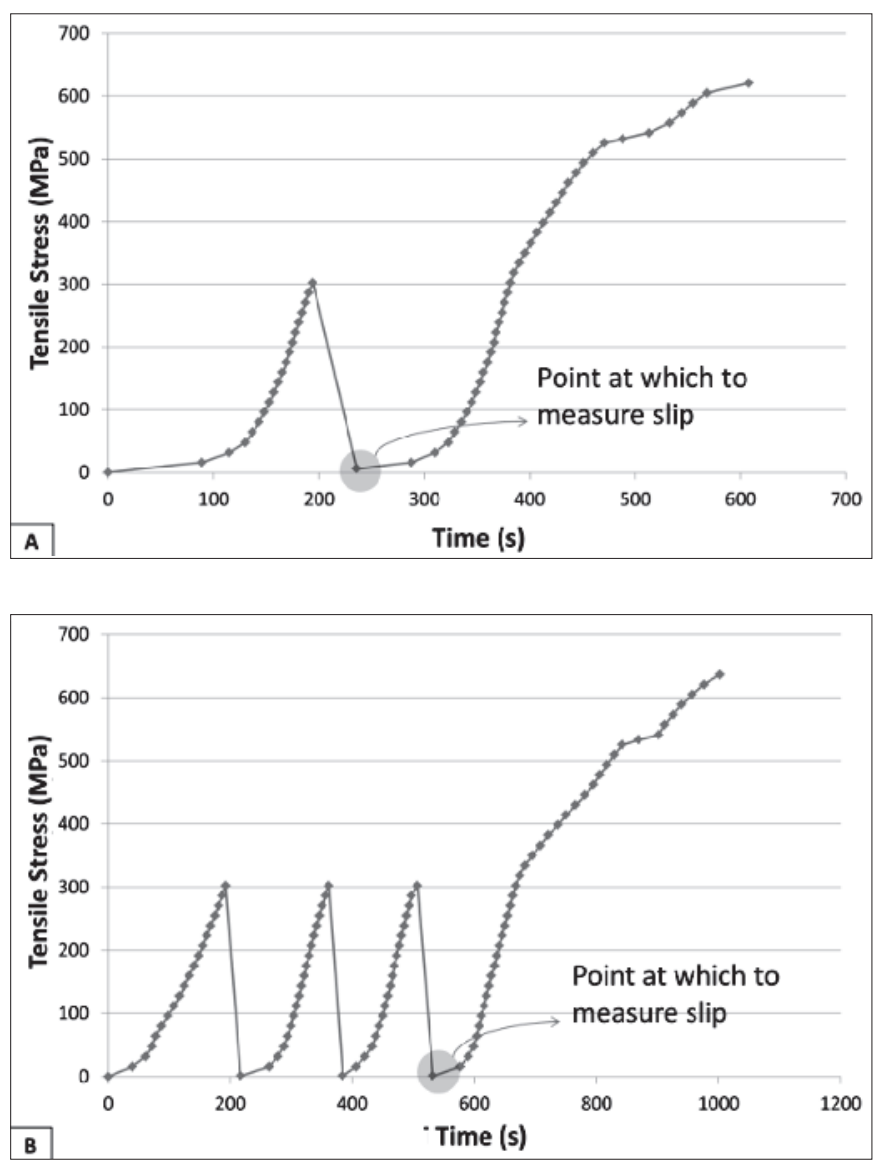

\section{Figure 14}

Load cycle scheme for determining slip, modified from DS-G-6647-029202 [36] (A-Method 1) and ISO 15835 [1] (B-Methods 2 and 3) 
Table 4

Results from characterization tests of control bars

\begin{tabular}{ccc}
\hline Test sample & $\begin{array}{c}\text { Yield stress } \mathrm{f}_{\mathrm{y}} \\
(\mathrm{MPa})\end{array}$ & $\begin{array}{c}\text { Maximum tensile } \\
\text { stress } \mathrm{f}_{\text {st }} \\
(\mathbf{M P a})\end{array}$ \\
\hline $\mathrm{BC}-20 \mathrm{~mm}-1$ & 555 & 659 \\
$\mathrm{BC}-20 \mathrm{~mm}-2$ & 555 & 655 \\
$\mathrm{BC}-20 \mathrm{~mm}-3$ & 540 & 671 \\
$\mathrm{BC}-25 \mathrm{~mm}-1$ & 545 & 638 \\
$\mathrm{BC}-25 \mathrm{~mm}-2$ & 542 & 663 \\
$\mathrm{BC}-25 \mathrm{~mm}-3$ & 550 & 716 \\
\hline
\end{tabular}

\section{Results and discussion}

Six steel bar characterization tests and 36 tensile stress and slip tests were performed on bar spliced by taper-threaded couplers. Table 4 presents the results for the yield stress $\left(f_{y}\right)$ and the maximum tensile stress $\left(f_{s t}\right)$ of the control bars, while Table 5 and Table 6 show the results for these same parameters from the bars mechanically spliced with couplers, in addition to the relative slip value between steel bar and coupler. All samples evaluated, with and without mechanical splicing, reached a yield stress of at least $500 \mathrm{MPa}$ and a maximum tensile stress of at least $540 \mathrm{MPa}$, both values established by ABNT NBR 7480 [30].

\section{Table 5}

Results of performance tests on steel bars with taper-threaded mechanical splices

\begin{tabular}{|c|c|c|c|c|}
\hline Test sample & Method & $\begin{array}{l}\text { Yield stress } \mathrm{f}_{\mathrm{y}} \\
(\mathrm{MPa})\end{array}$ & $\begin{array}{c}\text { Maximum tensile stress } f_{s t} \\
(M P a)\end{array}$ & $\begin{array}{l}\text { Slip } \\
(\mathrm{mm})\end{array}$ \\
\hline RC-20mm-1 & \multirow{3}{*}{ Method 1} & 528 & 641 & 0.10 \\
\hline $\mathrm{RC}-20 \mathrm{~mm}-2$ & & 536 & 648 & 0.10 \\
\hline $\mathrm{RC}-20 \mathrm{~mm}-3$ & & 535 & 641 & 0.02 \\
\hline RC-20mm-4 & \multirow{3}{*}{ Method 2} & 541 & 646 & 0.11 \\
\hline $\mathrm{RC}-20 \mathrm{~mm}-5$ & & 541 & 633 & 0.02 \\
\hline $\mathrm{RC}-20 \mathrm{~mm}-6$ & & 535 & 630 & 0.12 \\
\hline RC-20mm-7 & \multirow{3}{*}{ Method 3} & 541 & 635 & 0.03 \\
\hline $\mathrm{RC}-20 \mathrm{~mm}-8$ & & 540 & 637 & 0.02 \\
\hline $\mathrm{RC}-20 \mathrm{~mm}-9$ & & 533 & 637 & 0.00 \\
\hline RC-25mm-1 & \multirow{3}{*}{ Method 1} & 565 & 702 & 0.03 \\
\hline $\mathrm{RC}-25 \mathrm{~mm}-2$ & & 553 & 688 & 0.05 \\
\hline $\mathrm{RC}-25 \mathrm{~mm}-3$ & & 570 & 693 & 0.01 \\
\hline RC-25mm-4 & \multirow{3}{*}{ Method 2} & 566 & 682 & 0.03 \\
\hline $\mathrm{RC}-25 \mathrm{~mm}-5$ & & 567 & 677 & 0.28 \\
\hline $\mathrm{RC}-25 \mathrm{~mm}-6$ & & 556 & 675 & 0.10 \\
\hline RC-25mm-7 & \multirow{3}{*}{ Method 3} & 565 & 681 & 0.02 \\
\hline $\mathrm{RC}-25 \mathrm{~mm}-8$ & & 565 & 679 & 0.01 \\
\hline RC-25mm-9 & & 565 & 674 & 0.03 \\
\hline
\end{tabular}

\section{Table 6}

Results of performance tests on steel bars with shear bolted mechanical splices

\begin{tabular}{|c|c|c|c|c|}
\hline Test sample & Method & $\begin{array}{l}\text { Yield stress } \mathrm{f}_{\mathrm{y}} \\
(\mathrm{MPa})\end{array}$ & $\begin{array}{l}\text { Maximum tensile stress } \mathrm{f}_{\mathrm{st}} \\
(\mathrm{MPa})\end{array}$ & $\begin{array}{l}\text { Slip } \\
(\mathrm{mm})\end{array}$ \\
\hline PAR-20mm-1 & \multirow{3}{*}{ Method 1} & 532 & 621 & 0.02 \\
\hline PAR-20mm-2 & & 535 & 649 & 0.07 \\
\hline PAR-20mm-3 & & 532 & 657 & 0.01 \\
\hline PAR-20mm-4 & \multirow{3}{*}{ Method 2} & 535 & 627 & 0.05 \\
\hline PAR-20mm-5 & & 532 & 605 & 0.15 \\
\hline PAR-20mm-6 & & 535 & 653 & 0.19 \\
\hline PAR-20mm-7 & \multirow{3}{*}{ Method 3} & 533 & 654 & 0.01 \\
\hline PAR-20mm-8 & & 538 & 641 & 0.05 \\
\hline PAR-20mm-9 & & 616 & 710 & 0.02 \\
\hline PAR-25mm-1 & \multirow{3}{*}{ Method 1} & 559 & 670 & 0.10 \\
\hline PAR-25mm-2 & & 560 & 661 & 0.10 \\
\hline PAR-25mm-3 & & 559 & 693 & 0.07 \\
\hline PAR-25mm-4 & \multirow{3}{*}{ Method 2} & 558 & 667 & 0.14 \\
\hline PAR-25mm-5 & & 564 & 640 & 0.30 \\
\hline PAR-25mm-6 & & 564 & 704 & 0.05 \\
\hline PAR-25mm-7 & \multirow{3}{*}{ Method 3} & 565 & 672 & 0.07 \\
\hline PAR-25mm-8 & & 564 & 642 & 0.06 \\
\hline PAR-25mm-9 & & 556 & 646 & 0.06 \\
\hline
\end{tabular}



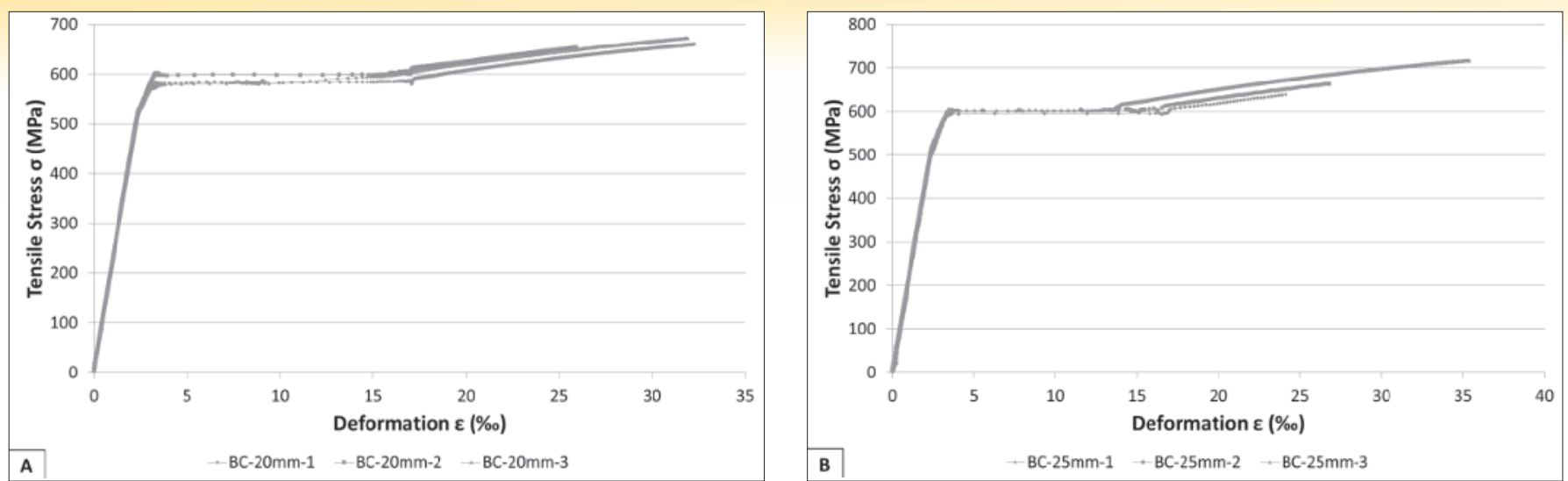

\section{Figure 15}

Stress-strain curves of the test control bars. A - BC-20mm; B - BC-25mm

Figure 15 shows the typical evolution of specific deformations, as a function of the tension, in the control bars used in this study. The behavior of the bars of both diameters can be seen to be analogous up until the point of rupture, as foreseen and specified by the manufacturer ArcelorMittal [42].

Figure 16 shows the evolution of specific deformations, as a function of stress, in the spliced bars denominated RC-20mm (Figure 18A), RC-25mm (Figure 18B), PAR-20mm (Figure 18C), and PAR-25mm (Figure 18D), with "RC" corresponding to taperthreaded couplers and "PAR" shear bolted couplers, followed by the diameter of the steel bar tested $(20$ and $25 \mathrm{~mm})$ and then by the number of the sample tested. Note that behavior is as expected for deformations in bars and couplers.
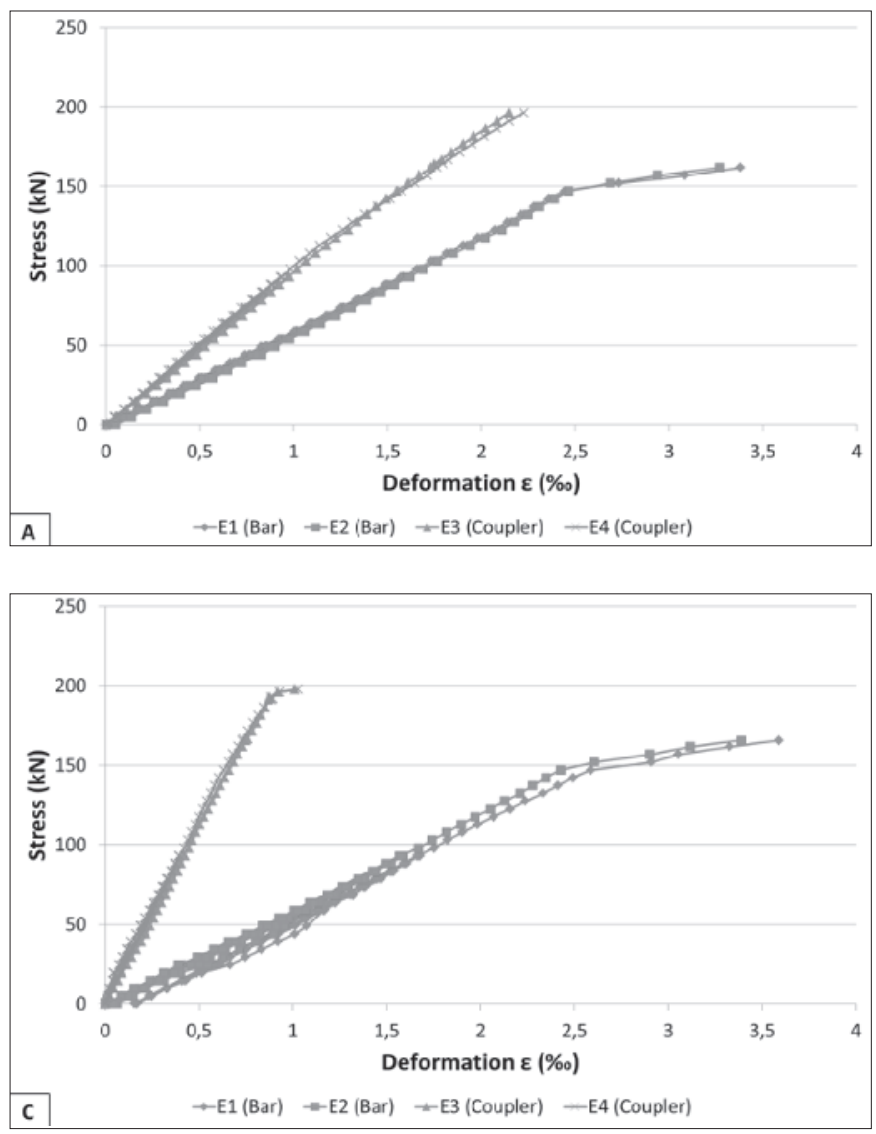

Figure 16

Stress-strain curves for mechanical splice tests. A - RC-20mm; B - RC-25mm; C - PAR-20mm and D - PAR-25mm
Regarding the maximum tensile stress, $f_{s t}$, determined in the tests, although it was found to be lower for the spliced bars when compared to the control bars in some tests, it should be emphasized that all the samples are in accordance with the requirements of ABNT NBR 7480 [30]; that is, for the CA 50 type steel bars used in this study, $f_{y}$ should be greater than $500 \mathrm{MPa}$, while $f_{s t}$ should be greater than $540 \mathrm{MPa}\left(1.08 f_{y}\right)$.

The ruptures of the spliced bars occurred almost entirely in the region of the splice, without affecting, however, the integrity of the couplers evaluated. In the case of the threaded couplers, the bar was pulled out of the coupler after breaking the thread crests through a combination of bending and shear stress. For the bolted couplers, the bolts ruptured through shearing. Figure 17 and
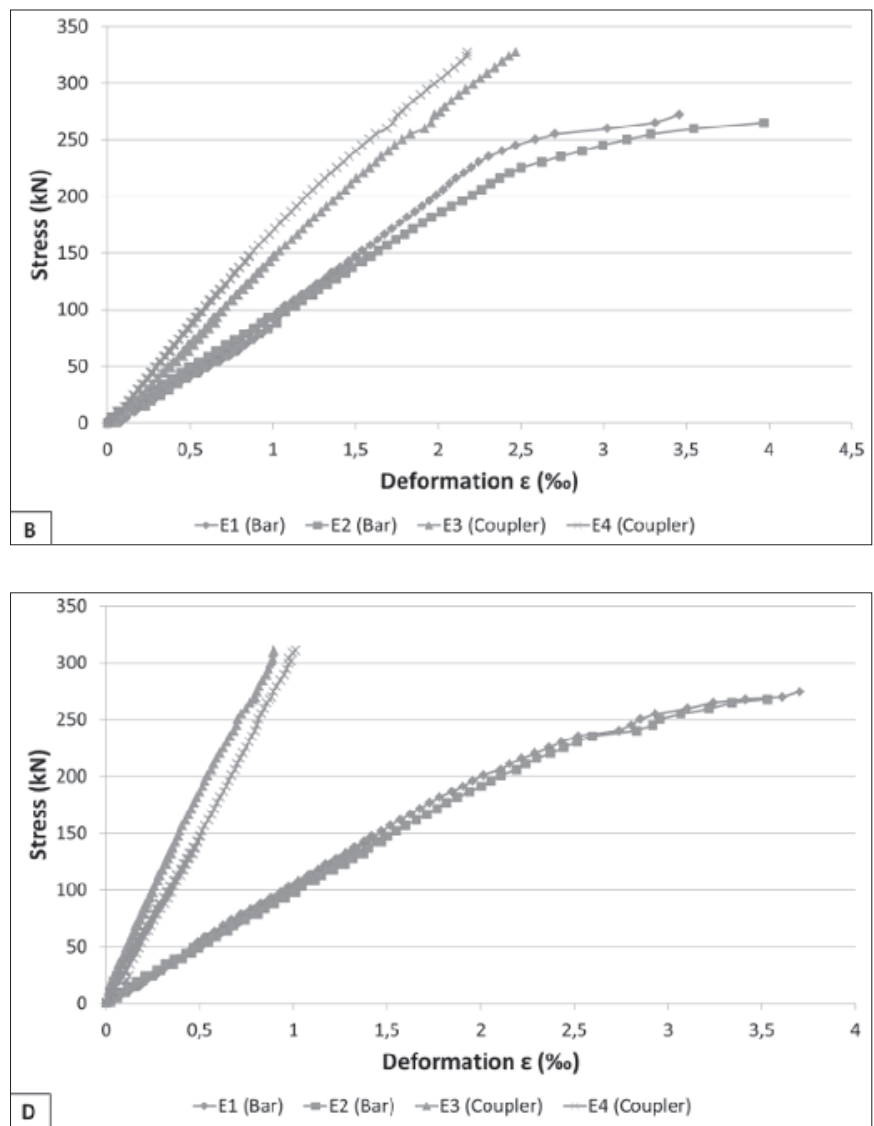
Figure 18 illustrate, respectively, the typical mode of rupture observed for splices with threaded and bolted couplers.

For the slip parameter, based on the requirements established by international standard ISO 15835 [1], and in Eletrobrás Eletronuclear's internal document, DS-G-6647-029202 [36], 83\% of the samples had slip values below the maximum allowed limit of $0.1 \mathrm{~mm}$. Samples that went above this limit were those based on Test Method 2, i.e. they used individual transducers to measure slip, performed at the end of three loading cycles.

The number of load cycles before measuring the final slip value and the installation of the transducers for measuring this slip are shown in Figure 19. The final values, very different, clearly show problems with the test methods being evaluated.

The bar evaluated by Test Method 1 (Figure 19A) showed $0.10 \mathrm{~mm}$ of slip at the end of a loading cycle. By Test Method 2, a similar bar (Figure 19) showed slips of $0.05 \mathrm{~mm}$ at the end of the first loading cycle, $0.10 \mathrm{~mm}$ at the end of the second cycle, and $0.15 \mathrm{~mm}$ at the end of the third loading cycle. Because the installation of the transducers, individually connected to the splicing bar, is the same for both methods, it can be concluded that this type of connection

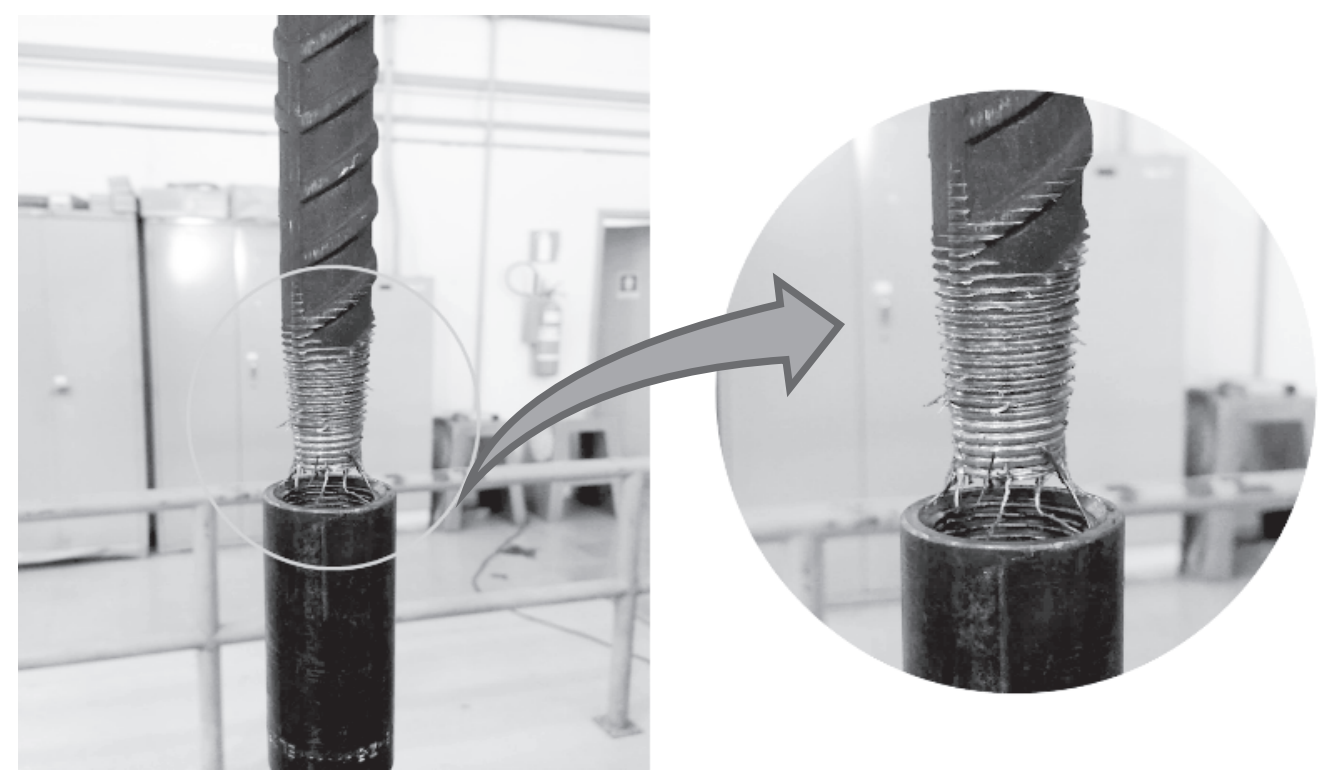

Figure 17

Detailed view post-rupture of spliced bar with taper-threaded coupler

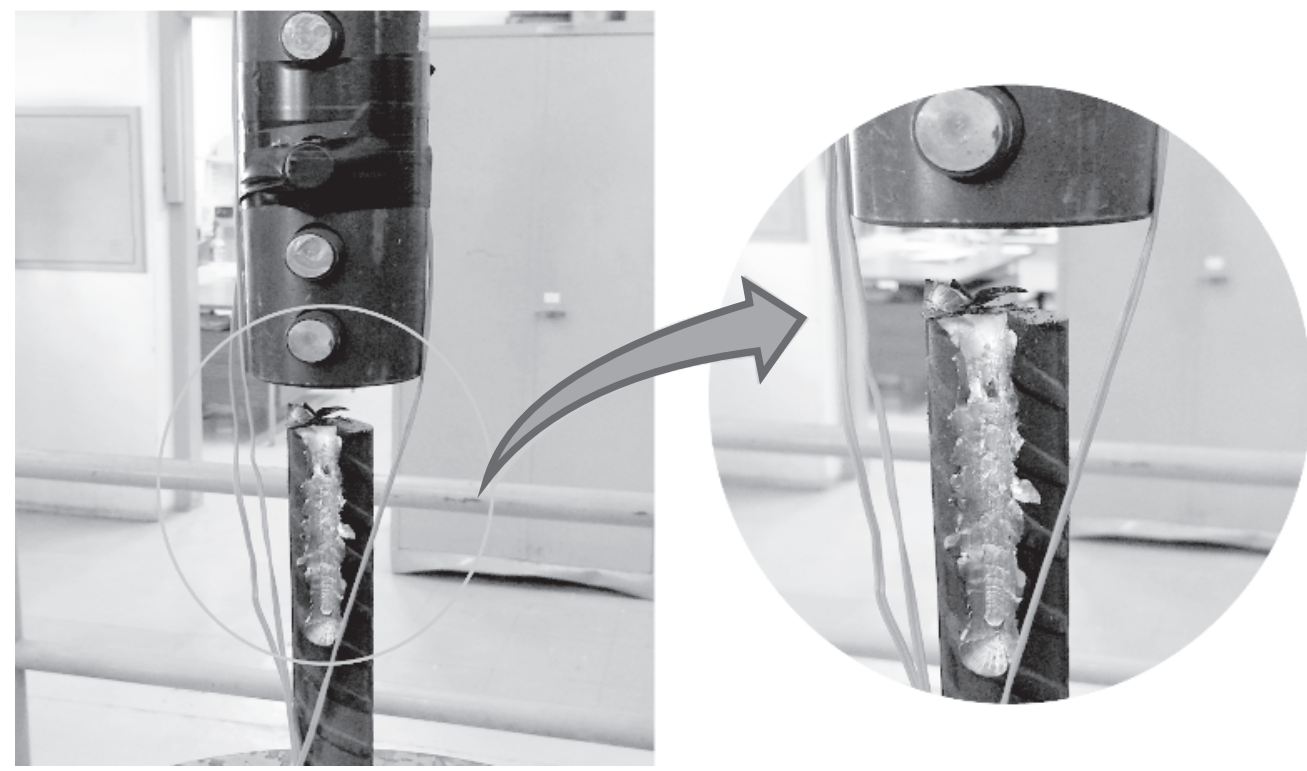

Figure 18

Detailed view post-rupture of spliced bar with shear bolted coupler 

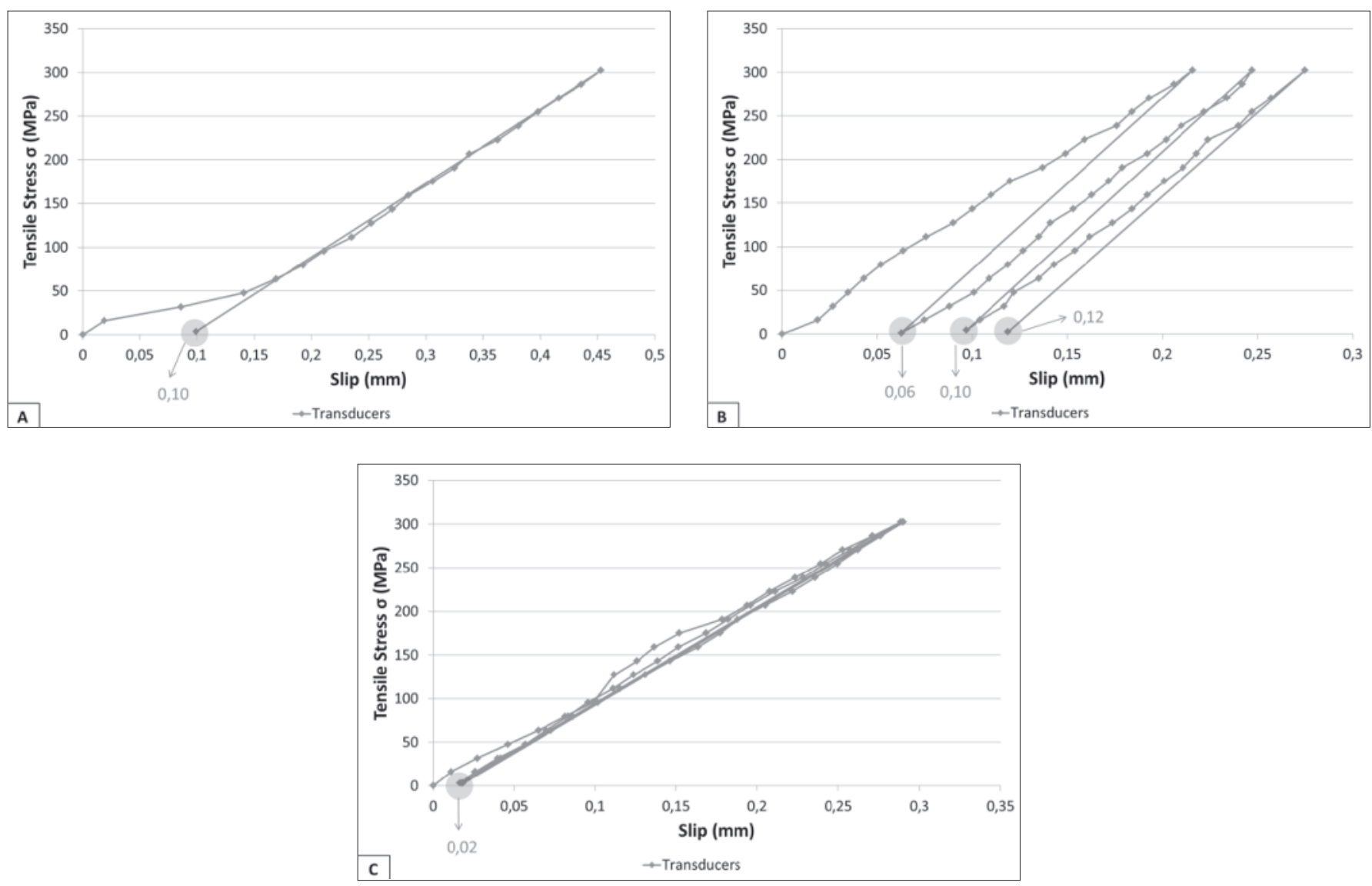

\section{Figure 19}

Evolution of the relative slip between bar and mechanical splice type RC-20mm. A - Method 1, B - Method 2 and $\mathrm{C}$ - Method 3

may be subject to possible transducer movements at the end of each load cycle; which, logically, could render both Method 1 and Method 2 unviable.

Figure 19C may be able to clarify some of the doubt expressed in the previous paragraph. Testing the same type of bar by Method 3 , employing a special apparatus (Figure 13) for slip measurement, resulted in identical slip values $(0.02 \mathrm{~mm})$ at the end of each loading cycle for the spliced bar. This result would only be possible if there was no movement in the transducers at the end of each load cycle; which demonstrates the efficiency of the proposed Test Method 3. Regarding the number of load cycles, the consistency in the slip results at the end of each cycle illustrated in Figure $19 \mathrm{C}(0.02 \mathrm{~mm})$ may indicate that only one load cycle may be sufficient to obtain the final slip. However, this fact should be explored more fully in future studies, where other types of mechanical splices and other diameters can be tested.

Although not specified in the instrumentation methodologies evaluated in this study, the insertion of the electric extensometers in the center of the splice coupler was very useful for measuring the deformation of the material and to verify if there was any influence on the slip parameter. In both cases, it has been noted that the splicing coupler does not deform during the course of the test and, consequently, this deformation value can be neglected in the evaluation of the test results.
However, because it is a question of performance testing of the splice and the coupler is an important part of the system, the instrumentation may indicate behavior not suitable for the element during the test and, therefore, should be maintained in any possible proposal for performance evaluation of the mechanical splicing system of steel bars in reinforced concrete structures.

\section{Conclusions}

1. In accordance with the results of the experimental program developed in this study, it was found that mechanical splicing using taper-threaded and shear bolted couplers is an apt solution to provide continuity and structural integrity to reinforced concrete constructions, as its behavior complied with all pre-established norms and standards. It is important to note that these findings are limited to the experiment performed and the materials used in this research. The generalization of the conclusions is possible only with continuity of studies, obviously involving other types of steel couplers available in Brazil (cold-swaged, straight-threaded, steel-filled, etc.).

2. Although it was not a parameter evaluated in this study, it is of the utmost importance that the effective test length of the sample being tested be based on the type of splice to be 
evaluated, i.e. in the case of splicing with couplers, the length of the coupler and the diameter of the steel bar should be considered. Therefore, it is proposed that a procedure similar to ISO 15835 [1] be adopted and later implemented in the future revision of ABNT NBR 8548 [2].

3. The use of electric extensometers at various points on the sample was of great importance for recording its deformation and, consequently, for guaranteeing adequate mechanical behavior when evaluating the performance of the mechanical splicing system.

4. The test procedure referred to in this study as "Method 3", with instrumentation based on Haber et al. [16] and Nguyen \& Mutusuyoshi [18], proved to be very efficient in obtaining the parameters of interest: tensile stress and slip. With the addition of four electrical extensometers, two on the steel bars and two on the splice couplers, in addition to the group of three displacement transducers connected to a special apparatus, it was possible to monitor deformation and slip in minute detail throughout the test.

5. Regarding the number of load cycles, the consistency in the slip results obtained at the end of each of the three cycles by Test Method 3 shows that only one load cycle may be sufficient to determine the final slip. However, this fact should be evaluated further in future studies, where other types of mechanical splices and other diameters should be tested.

6. The ABNT NBR 8548 [2] standard is effectively out of date and needs to be revised regarding the test procedures and parameters of interest to be obtained. It is therefore recommended to consider in its scope all methods and types of steel bar splice for reinforced concrete structures available in the national scenario, including in a future review, the slip parameter and its respective test method.

In conclusion, this article intends to contribute to the knowledge of the requirements necessary for the development of new experimental studies involving mechanical splices, as well as offering support for the discussion of performance evaluation procedures and instrumentation for these splices in future revisions of the Brazilian ABNT standard NBR 8548 [2].

\section{Acknowledgments}

The authors would like to thank the LENTON company for supplying the steel couplers and electric extensometers, as well as for their valuable technical information regarding the test methods applied. They would also like to thank Arcelor Mittal for donating all of the steel bars and a special thanks to Prof. Dr. Luiz Antonio Carneiro of the IME and the technicians of the Laboratory of Construction Materials and Concrete of the IME and the Laboratory of Structures and Materials at UNICAMP for their aid and assistance in carrying out the tests.

\section{Bibliographic references}

[1] INTERNATIONAL ORGANIZATION STANDARIZATION (ISO). Steels for the reinforcement of concrete Reinforcement couplers for mechanical splices of bars - Part 2: Test methods. ISO 15835-2. Geneva, Switzerland, 2009.
[2] ASSOCIAÇÃO BRASILEIRA DE NORMAS TÉCNICAS NBR 8548 - Barras de aço destinadas a armaduras de concreto armado com emenda mecânica ou por solda - Determinação da resistência à tração, Rio de Janeiro, 1984.

[3] SINGH R., Himanshu S. K., Bhalla N., Reinforcement couplers as an alternative to lap splices: A case study. International Journal of Engineering Research \& Technology, Vol 2 Issue 2, 2013, 6 p.

[4] NEUREDDINE, I. Plastic Energy Absorption Capacity of \#18 Reinforcing Bar Splices under Monotonic Loading. MSc Thesis, California State University, Sacramento, USA, 1996, 108 pp.

[5] HILLIS, D., and SAIIDI, M.S. Design, Construction, and Nonlinear Dynamic. Analysis of Three Bridge Bents Used in a Bridge System Test," Center for Civil Engineering Earthquake Research, Department of Civil and Environmental Engineering, University of Nevada, Reno, Nevada, Report No. CCEER-09-03, 2009, 82 pp.

[6] ROWELL, S.P., GREY, C.E., WOODSON, S.C., and HAGER, K.P. High Strain-Rate. Testing of Mechanical Couplers," US Army Corps of Engineers, Engineer Research and Development Center, Report No. ERDC TR-09-8, 2009, 74 pp.

[7] ALAM, M.S., YOUSEFF, M.A., and NEHDI, M.L.. "Exploratory Investigation on Mechanical Anchors for Connecting SMA Bars to Steel or FRP bars," Materials and Structures, 2010, Vol. 43, pp. 91-107.

[8] HUACO, G. and JIRSA, J. Performance of Damaged Column Retrofitted with Innovative Materials and Devices," 15th World Conference on Earthquake Engineering, 15WCEE, 2012, 10 pp.

[9] LLOYD, W. R. Qualification of the Bar-Lock Rebar Coupler for Use in Nuclear Safety-Related Applications Mechanical Testing Program and Performance Analysis," Idaho National Engineering and Environmental Laboratory Materials Department, Report No. INEEL/EXT-02-01387, 2001, 22 pp.

[10] AMERICAN SOCIETY FOR TESTING AND MATERIALS (ASTM). Standard Test Methods for Testing Mechanical Splices for Steel Reinforcing Bar. ASTM A1034A. Pennsylvania, USA, 2008.

[11] CONNAH, G. Prequalification of Mechanical Splices for Reinforcing Bars in Seismic Conditions. Australian Earthquake Engineering Society 2013 Conference, Tasmania, Australia, 2013, 7p.

[12] TASKIN, H. Determining the Mechanical Properties of Reinforcement Coupler Systems in Turkey. Special Edition Ejoir Magazine, Turkey. 2015, 10 p.

[13] KLIMENOV, V., OVCHINNIKOV, A. USTINOV, A., DANILSON, A. Stress-Strain State of Mechanical Rebar Couplings. Journal of Physics: Conference Series 671, 2016, 5 p.

[14] LING. J. H., RAHMAN, A. B. A., IBRAHIM, I. S., HAMID, Z. A. Behavior of grouted pipe splice under incremental tensile load. Construction and Building Materials 33, 2012, 90-98 pp.

[15] SEO, S.Y., NAM, B.R., KIM, S.G. Tensile strength of the grout-filled head-splice-sleeve. Construction and Building Materials 124, 2016, 155-166 pp.

[16] HABER, Z.B., Saiidi, M.S., Sanders, D.H. Behavior and simplified modeling of mechanical reinforcing bar splices. ACI Structural Journal March/April 2015, 179-189 pp. 
[17] CT670CALIFORNIADEPARTMENTOFTRANSPORTATION (CALTRANS), Division of Engineering Services. Method of tests for mechanical and welded reinforcing steel splices. Sacramento, USA, 2011.

[18] NGUYEN, D. P., MUTSUYOSHI, H. Influence of Quality of Mechanical Splices on Behavior of Reinforced Concrete Members. Research Report of Department of Civil and Environmental Engineering, Saitama Univ., Vol.41, 2015, 32-43 pp.

[19] FERREIRA, M. A. Estudo de deformabilidades de ligações para análise libnear em pórticos planos de elementos prémoldados de concreto, São Carlos, 1993, Dissertação (mestrado) - Escola de Engenharia da Universidade de São Paulo, 183 p.

[20] BALLARIN, A.W. Desempenho das ligações de elementos estruturais pré-moldados de concreto, São Carlos, 1993, Tese (doutorado) - Escola de Engenharia da Universidade de São Paulo, $187 \mathrm{p}$.

[21] FERREIRA, M. A. Deformabilidade de ligações viga-pilar de concreto pré-moldado, São Carlos, 1999, Tese (doutorado) Escola de Engenharia da Universidade de São Paulo, 253 p.

[22] JEREMIAS JUNIOR, A. C. Análise da estabilidade de estruturas pré-moldadas de concreto: influência das ligações semi-rígidas, São Carlos, 2007, Dissertação (mestrado) Universidade Federal de São Carlos, 218 p.

[23] SOUZA, A.S. Comportamento de elementos pré-moldados de concreto com ligações semi-rígidas, São Carlos, 2006, Dissertação (mestrado) - Universidade Federal de São Carlos, $118 \mathrm{p}$.

[24] CATOIA, B. Comportamento de vigas protendidas prémoldadas com ligações semi-rígidas, São Carlos, 2007, Dissertação (mestrado) - Universidade Federal de São Carlos, $215 \mathrm{p}$

[25] ASSOCIAÇÃO BRASILEIRA DE NORMAS TÉCNICAS (ABNT). Projeto e execução de estruturas de concreto prémoldado. ABNT NBR 9062. Rio de Janeiro, 2017.

[26] ORDOÑEZ, J.A.F. et al. Prefabrication teoría y prática. V.2. Barcelona, Spain, 1974.

[27] CHEOK, G.S.; LEW, H.S. Performance of precast concrete beam-t-column connections subject to cyclic loading. $\mathrm{PCl}$ Journal. V.36, n.3, 1991, 56-57 pp.

[28] HABER, Z.B.; SAIIDI, M.S.; SANDERS, D.H. Emulative column footing connections for seismic designs in a accelerate bridge construction. 4th ECCOMAS Thematic Conference on Computational Methods in Structural Dynamics and Earthquake Engineering, 2013, 8 p.

[29] YU, C.O.; ALRASYID H.; ZACHARY B. H.; HUNG J.L. Cyclic Behavior of Precast High-Strength Reinforced Concrete Columns. ACI Structural Journal Novembro/Dezembro, 12 p., 2015, 839-850 pp.

[30] ASSOCIAÇÃO BRASILEIRA DE NORMAS TÉCNICAS NBR 7480 - Aço destinado a armaduras para estruturas de concreto armado - Especificação, Rio de Janeiro, 2007

[31] DEUTSHES INSTITUT FUR BAUTECHNIK DIN 1045 Tragwerke aus Beton, Stahlbeton und Spannbeton - Teil 1: Bemessung und Konstruktion, 2008, 15 p.
[32] AUSTRIAN STANDARDS INSTITUTE - ÖNORM B 4700 - Stahlbetontragwerke-EUROCODE-nahe Berechnung, Bemessung und konstruktive Durchbildung, 2000, 20 p.

[33] FRENCH STANDARD - NF A 35-020-2-1:2011, Steel products - Mechanical splices and mechanical anchorages for ribbed or indented reinforcing steel - Part 2-1: Test methods for mechanical splices, 2011, $11 \mathrm{p}$.

[34] NATIONALE BEOORDELINGSSRICHTLIJIN, BRL-0504 Mechanische verbindingen van betonstaal, 2000, $31 \mathrm{p}$.

[35] BRITISH STANDARD - BS 8110 - Appendix TA1-B, Requirements for mechanical splices, 2011, $16 \mathrm{p}$.

[36] ELETROBRÁS ELETRONUCLEAR - Documento $n^{\circ} \mathrm{DS}-\mathrm{G}-$ 6647-029202 [11], 2000, 25 p.

[37] ASSOCIAÇÃO BRASILEIRA DE NORMAS TÉCNICAS NBR 11561 - Qualificação, execução e controle em emendas mecânicas de topo com luvas, destinadas a armações de concreto para centrais nucleoelétricas, Rio de Janeiro, 1990

[38] LENTON Taper Threaded Rebar Splicing Systems, Cleveland, USA, 2011, $20 \mathrm{p}$.

[39] LENTON LOCK Especificação Técnica Cleveland, USA, 2011, $1 \mathrm{p}$.

[40] ASSOCIAÇÃO BRASILEIRA DE NORMAS TÉCNICAS NBR 6152 - Materiais metálicos - Ensaio de tração à temperatura ambiente, Rio de Janeiro, 2002.

[41] INTERNATIONAL ORGANIZATION STANDARIZATION (ISO). Steel for the reinforcement and prestressing of concrete - Test methods - Part 1: Reinforcing bars, wire bar and wire. ISO 15630-1. Geneva, Switzerland, 2009.

[42] ARCELORMITTAL. Catálogo Técnico, São Paulo, 2015, 24 p. 